\title{
PERUBAHAN BENTUK BADAN HUKUM USAHA MILIK DAERAH BERDASARKAN PERATURAN PEMERINTAH NO. 54 TAHUN 2017 DALAM UPAYA PENINGKATAN PENDAPATAN ASLI DAERAH
}

\author{
Ibnu Sam Widodo \\ Fakultas Hukum Universitas Brawijaya \\ Jalan MT. Haryono 169 Malang Kode Pos: 65149, No telp: (0341) 553898 \\ Email: ibnusamwidodo@gmail.com
}

\begin{abstract}
The business entity regulated in Law No. 23 of 2014 which is then technically regulated in Government Regulation No. 54 of 2017 concerning Regional Owned Enterprises in which requires two forms of BUMD, namely regional companies or in short with Perseroda and the second form is Regional Public Company. In many areas there are many forms of business entities that are still in the form of Regional Companies, as a consequence of the enactment of Law No. 32 of 2004 on Local Government and Government Regulation No. 54 of 2017 on Regional Owned Enterprises, each form of Regional Company must be changed to a Regional Company or Regional Public Company. In this journal, the author will explore the procedures for the change from a Regional Company to a Regional Public Company based on Normative Juridical research methods using a statutory approach and literature studies with various literature books, journals, and articles related to the theme that the author adopted. The purpose of the authors to convey from the results of this study is how the influence of changes in the form of regional-owned enterprises in increasing the original income of the region so that the region.
\end{abstract}

Keywords: BUMD, Regional Public Companies, Regional Revenues.

\section{ABSTRAK}

Badan usaha yang diatur dalam UU Nomor 23 Tahun 2014 secara teknis di atur dalam PP Nomor 54 Tahun 2017 tentang BUMD yang di dalam nya mensyaratkan dua bentuk BUMD yaitu Perseroan Daerah dan Perusahaan Umum Daerah. Di banyak daerah bentuk badan usaha yang ada banyak yang masih berupa Perusahaan Daerah, sebagai konsekuensi dari berlaku nya UU Nomor 32 Tahun 2004 tentang PemDa dan PP Nomor 54 Tahun 2017 tentang BUMD maka setiap bentuk Perusahaan Daerah harus berubah menjadi Perseroan Daerah atau Perusahaan Umum Daerah. Dalam jurnal ini penulis akan mengupas tentang tata cara perubahan dari Perusahaan Daerah menjadi Perusahaan Umum Daerah berdasarkan metode penelitian Normatif Yuridis dengan menggunakan statute approach dan studi kepustakaan dengan berbagai literatur buku, jurnal dan artikel yang terkait. Tujuan yang ingin penulis sampaikan dari hasil penelitian ini adalah bagaimana pengaruh perubahan bentuk badan usaha milik daerah dalam peningkatan pendapatan asli daerah sehingga daerah.

Kata kunci : BUMD, Perusahaan Umum Daerah, Pendapatan Daerah.

\section{PENDAHULUAN}

Salah satu bentuk campur tangan pemerintah dalam sektor perekonomian yakni dengan mendirikan Badan Usaha Milik Negara yang selanjutnya disebut $\mathrm{BUMN}^{1}$, pendirian BUMN ini bertujuan untuk

1 BUMN adalah perusahaan-perusahaan yang didirikan oleh negara baik yang berbentuk badan hukum perdata maupun publik berdasarkan Undang-Undang Perusahaan Indonesia/Indonesische Bedrijvenwet, Staatsblad Tahun 1927 Nomor 419 dan perusahaan-perusahaan milik negara yang didirikan berdasarkan undang-Undang Kompatilbilitet Indonesia (Staatsblad Tahun 1925 Nomor 448), Baren Sipayung, Penyesuaian Bentuk Hukum BUMD Pasca Pemberlakuan PP No. 54 Tahun 2017 tentang BUMD, Subbagian Hukum Badan Pemeriksa Keuangan Republik Indonesia : Perwakilan Provinsi Kalimantan Timur, 2018. Hlm. 1 
melindungi cabang-cabang produksi yang penting bagi Negara dan yang menguasai hajat hidup orang banyak. Selanjutnya, dalam usaha memajukan kesejahteraan umum, penyelenggaraan pemerintahan dilaksanakan dengan menggunakan sistem desentralisasi kewenangan pemerintahan daerah yang termuat dalam Pasal 18 UUD NRI 1945.

Penyelenggaraan otonomi seluas-luasnya dengan disertai kewenangan mengatur dan mengurus rumah tangganya memerlukan tersedianya pendapatan daerah yang memadai baik yang berupa pendapatan asli ataupun pendapatan dari perimbangan keuangan antara pemerintah pusat dan daerah. Hal tersebut mengingat bahwa penyelenggaraan otonomi daerah senantiasa berorientasi pada peningkatan keejahteraan masyarakat dengan selalu memperhatikan kepentingan dan aspirasi masyarakat.

Dengan pertimbangan tersebut maka dikeluarkan adanya Undang-Undang Nomor 23 Tahun 2014 tentang Pemerintahan Daerah yang selanjutnya disebut UU PEMDA. Konsekuensi yang ditimbulkan dari adanya UU Pemda yakni campur tangan pemerimtah dalam sektor perekonomian tidak hanya dilakukan di pusat saja melalui BUMN, namun pemerintah daerah dalam hal ini juga memiliki kewenangan untuk ikut andil dalam sektor perekonomian daerah melalui Badan Usaha Milik Daerah ${ }^{2}$ yang selanjutnya disebut BUMD.

Dengan dikeluarkannya UU Pemda ini, telah diatur lebih jelas mengenai definisi, tujuan, dasar pendirian, sumber permodalan, bentuk hukum, dan pengelolaan dari Badan Usaha Milik Daerah._UU Pemda ini pun memiliki bab tersendiri yang mengatur BUMD yang termuat dalam BAB XII. Berdasarkan ketentuan Pasal 331 Ayat (1) Undang-Undang Nomor 23 tahun 2014 daerah diberi wewenang untuk mendirikan BUMD.

Adapun tujuan pendirian BUMD tersebut yakni untuk memberikan manfaat bagi perkembangan perekonomian daerah pada umumnya; menyelenggarakan kemanfaatan umum berupa penyediaan barang dan/atau jasa yang bermutu bagi pemenuhan hajat hidup masyarakat sesuai kondisi, karakteristik dan potensi Daerah yang bersangkutan berdasarkan tata kelola perusahaan yang baik; dan memperoleh laba dan/atau keuntungan. ${ }^{3}$

Adapun bentuk atau jenis dari BUMD tersebut terdiri atas perusahaan umum daerah yang selanjutnya disebut PERUMDA ${ }^{4}$ dan perusahaan perseroan daerah yang selanjutnya

Badan Usaha Milik Daerah yang selanjutnya disingkat BUMD adalah badan usaha yang seluruh atau sebagian besar modalnya dimiliki oleh Daerah, Ibid. Baren Sipayung. Hlm.2

3 Pasal 331 Ayat (4) Undang-Undang Nomor 23 tahun 2014 tentang Pemerintahan Daerah.

4 (1) Perusahaan umum Daerah adalah BUMD yang seluruh modalnya dimiliki oleh satu Daerah dan tidak terbagi atas saham. (2) Dalam hal perusahaan umum Daerah akan dimiliki oleh lebih dari satu Daerah, perusahaan umum Daerah tersebut harus merubah bentuk hukum menjadi perusahaan perseroan Daerah. (3) 
disebut PERSERODA. ${ }^{5}$ hal tersebut termuat dalam ketentuan Pasal 331 ayat (3) UU Pemda, namun permasalahan hukumnya adalah pengaturan tersebut seolah-olah meniadakan BUMD yang sudah ada sebelum UU Pemda yakni Perusahaan Daerah dan PT. ${ }^{6}$ UU Pemda dalam hal ini berarti hanya mengatur secara limitatif bentuk badan hukum BUMD yaitu perusahaan umum daerah dan perusahaan perseroan daerah saja, tanpa mengatur tentang penyelarasan atas bentuk badan hukum BUMD yang sudah ada sebelum diberlakukannya UU Pemda tersebut. $^{7}$

Adapun ketentuan lebih lanjut terkait BUMD ini diatur dalam Peraturan Pemerintah Republik Indonesia Nomor 54 Tahun 2017 tentang Badan Usaha Milik Daerah yang selanjutnya disebut PP No.54 Tahun 2017. Dalam PP tersebut menyatakan bahwa Kepala Daerah merupakan pemegang kekuasaan pengelolaan keuangan Daerah dan mewakili Pemerintah Daerah dalam kepemilikan Kekayaan Daerah Yang Dipisahkan.

Adapun kekuasaan yang dimaksud meliputi: Penyertaan modal; subsidi, penugasan; penggunaan hasil pengelolaan
Kekayaan Daerah Yang Dipisahkan; serta pembinaan dan pengawasan terhadap penyertaan modal pada BUMD. Kepala daerah mewakili pemerintah daerah dalam kepemilikan kekayaan daerah yang dipisahkan pada PERUMDA dan PERSERODA. Pada PERUMDA kepala daerah berkedudukan sebagai pemilik modal, sedangkan pada PERSERODA ia berkedudukan sebagai pemegang saham. Dari pemaparan diatas penulis tertarik untuk melakukan penelitian terhadap perubahan bentuk badan hokum usaha milik daerah berdasarkan PP No 54 Tahun 2017 tentang Badan Usaha Milik Daerah dalam upaya peningkatan pendapatan asli daerah.

Dalam penyusunan naskah penelitian ini menggunakan penelitian hukum normatif. Penelitian hukum normatif, juga disebut penelitian hukum doktriner, adalah penelitian hukum yang dilakukan dengan cara meniliti bahan pustaka yang difokuskan untuk mengkaji penerapan kaidah atau normanorma dalam hukum positif.

Berdasarkan pendapat dari Mukti Fadjar dan Yulianto, ${ }^{8}$ bahwa penelitian hukum normatif terdiri dari norma dasar (norm basic)

Perusahaan umum daerah dapat membentuk anak perusahaan dan/atau memiliki saham pada perusahaan lain. Pasal 334 Undang-Undang Nomor 23 tahun 2014 tentang Pemerintahan Daerah.

5 Perusahaan Perseroan Daerah adalah BUMD yang berbentuk perseroan terbatas yang modalnya terbagi dalam saham yang seluruhnya atau paling sedikit $51 \%$ (lima puluh satu persen) sahamnya dimiliki oleh satu Daerah. Pasal 339 Undang-Undang Nomor 23 tahun 2014 tentang Pemerintahan Daerah.

6 Pasal 2 Peraturan Menteri Dalam Negeri Nomor 3 Tahun 1998 tentang Bentuk Hukum Badan Usaha Milik Daerah.

7 Op.Cit., Baren Sipayung. Hlm. 2.

8 Mukti Fadjar dan Yulianto Achmad, (2010), Dualisme Penelitian Hukum Normatif dan Empiris, Yogyakarta; Pustaka Pelajar. Hlm. 36. 
asas-asas hukum, kitab undang-undang atau peraturan perundang-undangan, doktrin atau ajaran hukum, dokumen perjanjian kontrak, keputusan pengadilan, keputusan birokrasi dan segala bentuk dokumen hukum yang dibuat secara formal dan mempunyai kekuatan hukum. Untuk mengkaji permasalahan yang ada, maka penggalian bahan hukum primer menggunakan beberapa pendekatan yakni: Statute approach (pendekatan perundang-undangan). ${ }^{9}$

Pendekatan Perundangan-undangan dilakukan dengan menelaah semua undangundang dan regulasi pelaksanaan yang bersangkut paut dengan isu perencanaan pembangunan daerah khususnya di bidang peningkatan Pendapatan Asli Daerah (PAD) serta pelayanan publik melalui perubahan bentuk badan hokum milik Pemerintah Daerah sesuai dengan ketentuan hukum yang berlaku serta pemanfaatannya dapat terus dikembangkan.

Pendekatan yang kedua adalah conceptual approach yakni pendekatan melalui prinsipprinsip dan konsep-konsep yang dapat ditemukan dalam perundang-undangan sarjana ataupun doktrin-doktrin hukum yang relevan dengan kajian penelitian tentang perubahan bentuk badan hokum milik pemerintah daerah. Teknik penelusuran bahan hukum dalam penelitian ini dilakukan melalui studi pustaka baik berupa informasi tertulis dari buku maupun dokumen hukum, selain itu penulis juga mengguanakn informasi elektronik yang diperoleh melalui penelusuran internet. Setelah semua bahan terkumpul selanjutnya penulis menyusun dan menganalisis data. Dalam proses analisis data penulis menggunakan penalaran deduktif ${ }^{10}$ dengan metode deskriptif. ${ }^{11}$

Setelah proses analisis, dilakukan proses sintesis dengan menarik dan menghubungkan rumusan masalah, tujuan penulisan serta pembahasan yang dilakukan. Selain itu penulis juga menggunakan metode analisis normatif, yakni dengan cara menginterpretasikan dan mendiskusikan bahan hasil penelitian berdasarkan pada pengertian hukum, norma hukum, teori-teori hukum serta doktrin yang berkaitan dengan pokok permasalahan. Berikutnya ditarik simpulan yang kemudian direkomendasikan beberapa hal sebagai upaya transfer gagasan. Serta dalam melakukan proses pengolahan data yang telah diperoleh, dilakukan proses Editing, yakni pengecekan terhadap

9 Peter Mahmud Marzuki, (2005), Penelitian Hukum, Jakarta; Kencana. Hlm. 93.

10 Langkah berpikir dengan mengumpulkan pernyataan yang bersifat umum untuk selanjutnya ditarik suatu kesimpulan yang bersifat khusus. Jujun S. Suriasumantri, (2001), Filsafat Ilmu: Sebuah Pengantar Populer, Jakarta; Pustaka Sinar Harapan. Hlm. 49.

11 Metode yang digunakan untuk mempelajari permasalahan yang ada dalam masyarakat, serta tata cara yang berlaku dalam masyarakat sehari-hari serta situasi tertentu. Tujuan dari metode deskriptif ini adalah untuk membuat gambaran secara sistematis, faktual dan akurat mengenai fakta-fakta, sifat-sifat, serta hubungan yang antar fenomena yang diteliti untuk mendapatkan suatu pemecahan. Moh Nazir, (2005), Metode Penelitian, Jakarta; Ghalia Indonesia. Hlm. 35. 
kemungkinan adanya kesalahan atau ketidak serasian informasi ${ }^{12}$ dan Classifying, yaitu pengaturan data untuk diadakan suatu analisis. $^{13}$

\section{PEMBAHASAN}

BUMD dapat melakukan perubahan bentuk hukum, ${ }^{14}$ Perubahan bentuk hukum sebagaimana dimaksud dilakukan dalam rangka mencapai tujuan BUMD dan restrukurasi. $^{15}$ Restrukturisasi meliputi Restrukturisasi regulasi dan/atau Restrukturisasi perusahaan. ${ }^{16}$ Restrukturisasi dilaksanakan melalui:

a. Restrukturisasi internal yang mencakup keuangan, manajemen, operasional, sistem, dan prosedur;

b. Penataan hubungan fungsional antara Pemerintah Daerah dan BUMD untuk menetapkan arah dalam rangka pelalsanaan kewajiban pelayanan publik. ${ }^{17}$ Perubahan bentuk hukum BUMD terdiri atas:

a. Perubahan bentuk hukum perusahaan umum daerah menjadi perusahaan perseroan Daerah; dan b. Perubahan bentuk hukum perusahaan perseroan Daerah menjadi perusahaan umum Daerah. ${ }^{18}$

Adapun perubahan bentuk hukum BUMD sebagaimana dimaksud ditetapkan dengan Perda. ${ }^{19}$ Perubahan bentuk hukum BUMD dilakukan dengan terlebih dahulu melakukan kajian paling sedikit terhadap:

a. kesesuaian bentuk hukum;

b. kewajiban; dan

c. kekayaan BUMD. ${ }^{20}$

Kewajiban dan kekayaan sebagaimana dimaksud diperhitungkan secara proporsional. $^{21}$ Perusahaan daerah yang menjadi BUMD dengan kepemilikan saham 1 (satu) daerah dibawah 51\% (lima puluh satu persen), daerah tersebut wajib menyesuaikan kepemilikan sahamnya menjadi paling sedikit $51 \%$ (lima puluh satu persen) sesuai dengan ketentuan peraturan perundang-undangan. ${ }^{22}$ Penyesuaian sebagaimana dimaksud dilakukan oleh Kepala Daerah dalam jangka waktu paling lama 5 tahun sejak Peraturan Menteri Dalam Negeri Republik Indonesia Nomor 118 Tahun 2018 ini diundangkan. ${ }^{23}$ dengan memperhatikan:

12 Lexy J. Moleong, (2007), Metodelogi Penelitian Kualitatif, Bandung; Rosda. Hlm. 216.

13 Redenbregt, (1978), Metode dan Teknik Penelitian Masyarakat, Jakarta; Gramedia. Hlm. 126.

14 Pasal 114 Ayat (1) Peraturan Pemerintah Nomor 54 Tahun 2017.

15 Pasal 114 Ayat (2) Peraturan Pemerintah Nomor 54 Tahun 2017.

16 Pasal 113 Ayat (1) Peraturan Pemerintah Nomor 54 Tahun 2017.

17 Pasal 113 Ayat (2) Peraturan Pemerintah Nomor 54 Tahun 2017.

18 Pasal 114 Ayat (3) Peraturan Pemerintah Nomor 54 Tahun 2017.

19 Pasal 35 Ayat (4) Peraturan Menteri Dalam Negeri Republik Indonesia Nomor 118 Tahun 2018.

20 Pasal 35 Ayat (5) Peraturan Menteri Dalam Negeri Republik Indonesia Nomor 118 Tahun 2018.

21 Pasal 35 Ayat (6) Peraturan Menteri Dalam Negeri Republik Indonesia Nomor 118 Tahun 2018.

22 Pasal 36 Ayat (1) Peraturan Menteri Dalam Negeri Republik Indonesia Nomor 118 Tahun 2018.

23 Pasal 36 Ayat (3) Peraturan Menteri Dalam Negeri Republik Indonesia Nomor 118 Tahun 2018. 
a. visi dan misi Kepala Daerah;

b. kinerja BUMD;

c. tingkat kesehatan BUMD;

d. kualitas dan kuantitas pelayanan BUMD bagi masyarakat; dan

e. kemampuan Anggaran Pendapatan dan Belanja Daerah. ${ }^{24}$

Adapun, dasar hukum pembentukan BUMD yakni Pasal 304 ayat (1) UndangUndang Nomor 23 Tahun 2014 tentang Pemerintahan Daerah yang selanjutnya disebut sebagai UU Pemda, yang menyatkaan bahwa daerah dapat melakukan penyertaan modal pada badan usaha milik negara dan/atau BUMD dan Bab XII tentang BUMD (Pasal 331 s.d. 343) UU Pemda jo. PP BUMD. Sumber Modal BUMD terdiri atas penyertaan modal daerah (uang dan barang milik Daerah), pinjaman, hibah dan sumber modal lainnya (kapitalisasi cadangan, keuntungan revaluasi aset, dan agio saham).Berdasarkan Pasal 333 ayat (2) UU Pemda, penyertaan modal Daerah ditetapkan dengan Perda.

\begin{abstract}
Selanjutnya, pendirian BUMD didasarkan pada kebutuhan Daerah dan kelayakan bidang usaha BUMD yang akan dibentuk. Lebih lanjut, kebutuhan daerah dikaji melalui studi yang mencakup aspek pelayanan umum dan kebutuhan masyarakat diantaranya air minum, pasar, transportasi. Selanjutnya, kelayakan bidang usaha BUMD dikaji melalui analisis terhadap kelayakan ekonomi, analisis pasar dan pemasaran dan analisis kelayakan keuangan serta analisis aspek lainnya. Selain itu, sebagai ketentuan lebih lanjut tentang pendirian, organ perusahaan umum daerah/perusahaan perseroan daerah, laba perusahaan umum daerah, restrukturisasi perusahaan umum daerah, pembubaran perusahaan umum daerah/perusahaan perseroan daerah, dan pengelolaan BUMD, sebagaimana diatur dalam Pasal 331 ayat (6), 335 ayat (2), 336 ayat (5), 337 ayat (2), 338 ayat (4), 340 ayat (2), 342 ayat (3) dan 343 ayat (2) UU Pemda, maka diundangkanlah Peraturan Pemerintah Republik Indonesia Nomor 54 Tahun 2017 tentang Badan Usaha Milik Daerah (PP BUMD). Berikut merupakan pengaturan antara perusahaan Perseroan Daerah dalam UU Pemda dan PP BUMD: ${ }^{25}$ PERUMDA
\end{abstract}

24 Pasal 36 Ayat (2) Peraturan Menteri Dalam Negeri Republik Indonesia Nomor 118 Tahun 2018.

25 Baren Sipayung, Penyesuaian Bentuk Hukum BUMD Pasca Pemberlakuan PP Nomor 54 Tahun 2017 Tentang BUMD, Subbagian Hukum, Badan Pemeriksa Keuangan Republik Indonesia Perwakilan Provinsi Kalimantan Timur. Hlm. 12. 
Perusahaan umum Daerah adalah BUMD yang seluruh modalnya dimiliki oleh satu Daerah dan tidak terbagi atas saham.(Pasal 334 UU Pemda jo.Pasal 5 ayat (1) PP BUMD)
Perusahaan umum Daerah dapat membentuk anak perusahaan dan/atau memiliki saham pada perusahaan lain. (Pasal 334 ayat (3) UU Pemda jo. Pasal 107 ayat (1) dan (2) PP BUMD
Organ perusahaan umum Daerah terdiri atas kepala daerah selaku wakil Daerah sebagai pemilik modal, direksi dan dewan pengawas. (Pasal 335 ayat (1) UU Pemda)

Laba perusahaan umum Daerah ditetapkan oleh kepala daerah selaku wakil daerah sebagai pemilik modal sesuai dengan ketentuan anggaran dasar dan ketentuan peraturan perundangundangan. (Pasal 336 ayat (1) UU Pemda

jo.Pasal 100 ayat (4) PP BUMD)

Laba perusahaan umum Daerah yang menjadi hak Daerah disetor ke kas Daerah setelah disahkan oleh kepala daerah selaku wakil Daerah sebagai pemilik modal. (Pasal 336 ayat (2) UU Pemda)

Laba perusahaan umum Daerah sebagaimana dimaksud pada ayat (2) dapat ditahan atas persetujuan kepala daerah selaku wakil Daerah sebagai pemilik modal. (Pasal 336 ayat (3) UU Pemda)

Laba perusahaan umum Daerah sebagaimana dimaksud pada ayat (3) digunakan untuk keperluan investasi kembali (reinvestment) berupa penambahan, peningkatan dan perluasan
Perusahaan Perseroan Daerah adalah BUMD yang berbentuk perseroan terbatas yang modalnya terbagi dalam saham yang seluruhnya atau paling sedikit $51 \%$ (lima puluh satu persen) sahamnya dimiliki oleh satu Daerah. (Pasal 339 ayat (1) UU Pemda jo. Pasal 5 ayat (2) PP BUMD)

Dalam hal pemegang saham perusahaan perseroan Daerah terdiri atas beberapa Daerah dan bukan Daerah, salah satu Daerah merupakan pemegang saham mayoritas. (Pasal 339 ayat (3) UU Pemda

Jo. Pasal 6 ayat (2) PP BUMD)

Perusahaan perseroan Daerah dapat membentuk anak perusahaan dan/atau memiliki saham pada perusahaan lain. (Pasal 341 ayat (1) UU Pemda

jo. Pasal 107 ayat (1) dan (2) PP BUMD)

Pembentukan anak perusahaan didasarkan atas analisa kelayakan investasi oleh analis investasi yang profesional dan independen. (Pasal 341 ayat (2) UU Pemda)

Organ perusahaan perseroan Daerah terdiri atas rapat umum pemegang saham, direksi, dan komisaris. (Pasal 340 ayat (1) UU Pemda)

Penggunaan laba perusahaan
perseroan Daerah dilaksanakan sesuai dengan ketentuan peraturan perundangundangan yang mengatur mengenai perseroan terbatas. (Pasal 105 ayat (1) PP BUMD) Dividen perusahaan perseroan Daerah yang menjadi hak Daerah merupakan penerimaan Daerah setelah disahkan oleh RUPS. (Pasal 105 ayat (1) PP BUMD) BUMD melaksanakan tanggung jawab sosial dan lingkungan dengan cara menyisihkan sebagian laba bersih. (Pasal 106 ayat (1) PP BUMD)

Perubahan laba untuk tanggung jawab sosial dan lingkungan diprioritaskan untuk keperluan pembinaan usaha mikro, usaha kecil, dan koperasi. (Pasal 106 ayat (2) PP BUMD). 
prasarana dan sarana pelayanan fisik dan nonfisik serta untuk peningkatan kuantitas, kualitas dan kontinuitas pelayanan umum, pelayanan dasar dan usaha perintisan. (Pasal 336 (4))

Perusahaan umum Daerah dapat melakukan restruksturisasi untuk menyehatkan perusahaan umum Daerah agar dapat beroperasi secara efisien, akuntabel, transparan, dan profesional. (Ps 337 ayat (1) UU Pemda jo. Pasal 112 ayat (1) PP BUMD) Restrukturisasi bertujuan untuk:

a. meningkatkan kinerja dan nilai BUMD;

b. memberikan manfaat berupa dividen dan pajak kepada negara dan Daerah; dan/atau

c. menghasilkan produk dan layanan dengan harga yang kompetitif kepada konsumen. (Pasal 112 ayat (2) PP BUMD) Restrukturisasi meliputi Restrukturisasi regulasi dan/atau Restrukturisasi perusahaan. (Pasal 113 ayat (1) PP BUMD)

Perusahaan umum Daerah dapat dibubarkan pembubatannya ditetapkan dengan Perda. (Pasal 338 ayat (1) dan (2) UU Pemda jo. Pasal 124 ayat (1) PP BUMD)

Kekayaan perusahaan umum Daerah yang telah dibubarkan dan menjadi hak Daerah dikembalikan kepada Daerah. (Pasal 338 ayat (3) UU Pemda jo. Pasal 124 ayat (3) PP BUMD)

Perusahaan perseroan daerah dapat dibubarkan. (Pasal 342 ayat (1) UU Pemda jo.Pasal 124 ayat (1) PP BUMD)

Kekayaan Daerah hasil pembubaran perusahaan perseroan Daerah yang menjadi hak Daerah dikembalikan kepada Daerah. (Pasal 342 ayat (3) UU Pemda jo. Pasal 124 ayat (3) PP BUMD)

Berdasarkan Pasal 343 ayat (1) UU Pemda hukum; kepailitan; dan penggabungan, menyatakan bahwa pengelolaan BUMD peleburan, dan pengambilalihan. ${ }^{26}$

paling sedikit harus memenuhi unsur: tata cara

Apabila dilihat dari sejarah pengaturan penyertaan modal; organ dan kepegawaian; terkait BUMD sebelum dikeluarkannya UU tata cara evaluasi; tata kelola perusahaan yang Pemda, sudah ada terlebih dahulu ketentuan baik; perencanaan, pelaporan, pembinaan, Permendagri 3/1998. Di dalam Pasal 2 pengawasan; kerjasama; penggunaan laba; Permendagri 3/1998, bentuk hukum BUMD penugasan Pemerintah Daerah; pinjaman; dapat berupa Perusahaan Daerah (PD) atau satuan pengawas intern, komite audit dan komite lainnya; penilaian tingkat kesehatan, restrukturisasi, privatisasi; perubahan bentuk Perseroan Terbatas (PT). Lebih lanjut, di dalam Pasal 5 Permendagri 3/1998 pun sudah jelas pula prosedur perubahan bentuk hukum BUMD, yaitu:

26 Ibid. Hlm. 13. 
1. Mengajukan permohonan prinsip tentang perubahan bentuk hukum kepada Menteri;

2. Menetapkan Peraturan Daerah Tingkat I atau Tingkat II tentang Perubahan Bentuk Hukum Badan Usaha Milik Daerah dari Perusahaan Daerah menjadi Perseroan Terbatas;

3. Pembuatan Akte Notaris pendirian sebagai Perseroan Terbatas.

Akan tetapi, seiring dengan perubahan peraturan perundang-undangan, maka Permendagri 3/1998 telah dicabut karena bertentangan dengan UU Pemda melalui Permendagri 11/2016. Dalam Hukum Administrasi Negara, kewenangan Kementerian Dalam Negeri adalah sesuai dengan asas terdapat asas contrarius actus, yakni bahwa badan atau pejabat tata usaha negara yang menerbitkan keputusan tata usaha negara dengan sendirinya juga berwenang untuk membatalkannya. Asas ini

\begin{tabular}{|c|c|}
\hline UU Pemda & PP BUMD \\
\hline Pasal 402 ayat (2): & Pasal 114 ayat (1): BUMD \\
\hline BUMD yang telah ada sebelum & Dapat melakukan perubahan bentuk \\
\hline Undang-Undang ini berlaku, wajib & hukum. Pasal 114 ayat (3): Perubahan \\
\hline menyesuaikan dengan ketentuan dalam & bentuk hukum BUMD terdiri atas: \\
\hline Undang-Undang ini dalam jangka waktu & a. perubahan bentuk hukum perusahaan \\
\hline paling lama 3 (tiga) tahun terhitung sejak & umum Daerah menjadi perusahaan \\
\hline Undang-Undang ini diundangkan & perseroan Daerah; dan \\
\hline & b. perubahan bentuk hukum perusahaan \\
\hline & $\begin{array}{l}\text { perseroan Daerah menjadi perusahaan } \\
\text { umum Daerah. }\end{array}$ \\
\hline & $\begin{array}{l}\text { Pasal } 139 \text { ayat (1): Perusahaan daerah } \\
\text { yang telah didirikan sebelum berlakunya }\end{array}$ \\
\hline
\end{tabular}

berlaku meskipun dalam keputusan tata usaha negara tersebut tidak dicantumkan klausula pengaman yang lazim: "apabila dikemudian hari ternyata ada kekeliruan atau kehilafan maka keputusan ini akan ditinjau kembali”. Asas contrarius actus ini berlaku tidak hanya untuk keputusan administrasi negara, namun juga asas peraturan perundang-undangan, dimana yang berwenang mencabut suatu peraturan perundang-undangan adalah pembentuknya itu sendiri dan tidak dapat dilakukan oleh peraturan atau lembaga yang lebih rendah. ${ }^{27}$

Adapun konsekuensi hukum dengan diberlakukannya Permendagri 11/2016 adalah setelah dikeluarkannya UU Pemda, belum ada peraturan pelaksanaan yang mengatur terkait perubahan bentuk badan hukum BUMD tersebut. Apabila diteliti terkait penyesuaian atas bentuk hukum BUMD, dalam UU Pemda dan PP BUMD terdapat kontradiksi sebagai berikut: ${ }^{28}$ 


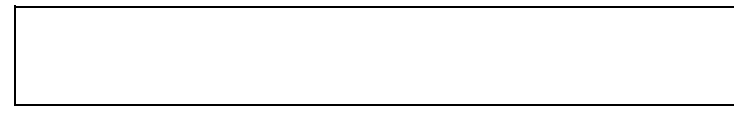

Antara Pasal 402 ayat (2) UU Pemda dengan Pasal 114 ayat (1), (3), dan Pasal 139 ayat (1) PP BUMD menimbulkan ketidaksinkronan \& ketidakharmonisasian yaitu:

1. Di dalam Pasal 402 ayat (2) UU Pemda, terdapat frasa "wajib", yang artinya adalah harus dilaksanakan sedangkan dalam Pasal 114 ayat (1) PP BUMD, terdapat frasa "dapat", yang artinya adalah pilihan atau tidak wajib dilaksanakan.

2. Di dalam Pasal 402 ayat (2) UU Pemda, diakui bahwa BUMD yang ada telah ada BUMD sebelum UU Pemda (yaitu Perusahaan Daerah (PD) atau Perseroan Terbatas (PT) sebagaimana diatur dalam Pasal 2 Permendagri 3/1998) tidak dapat dirubah bentuk badan hukumnya sesuai dengan ketentuan Pasal 114 ayat (3) PP BUMD, yaitu perusahaan umum daerah menjadi perusahaan perseroan daerah begitu pula sebaliknya perusahaan perseroan daerah menjadi perusahaan umum daerah.

3. Selain itu, di dalam Pasal 139 ayat (1) PP BUMD, pengertian BUMD sebagaimana dimaksud dalam Pasal 402 ayat (2) UU Pemda mengalami penyempitan makna bahwa perusahaan daerah adalah bukan
Peraturan Pemerintah ini dapat diubah menjadi BUMD.

BUMD. Berdasarkan Pasal 1 angka 40 UU Pemda, perusahaan daerah memenuhi kualifikasi sebagai BUMD karena badan usaha yang seluruh atau sebagian besar modalnya dimiliki oleh Daerah. $^{29}$

Dapat diartikan bahwa Pasal 114 ayat (1) dan (3) PP BUMD bertentangan dengan Pasal 402 ayat (2) UU Pemda karena tidak sesuai dengan asas lex superior derogat legi inferior dalam teori "Stuffen Bow" oleh Hans Kelsen, yaitu asas pembentukan peraturan perundang-undangan bahwa peraturan yang lebih tinggi mengesampingkan yang rendah. Selain itu, kekuatan hukum peraturan perundang-undangan sesuai dengan hierarki, yakni penjenjangan setiap jenis Peraturan Perundang-undangan yang didasarkan pada asas bahwa Peraturan Perundang-undangan yang lebih rendah tidak boleh bertentangan dengan Peraturan Perundang-undangan yang lebih tinggi. ${ }^{30}$

Namun dalam UU Pemda maupun PP BUMD secara tersirat sudah memuat indikasi pedoman bagi BUMD yang sudah ada sebelum diberlakukannya UU Pemda untuk menyesuaikan/merubah bentuk badan hukum BUMD tersebut adalah antara lain: ${ }^{31}$ 


\begin{tabular}{|c|c|}
\hline Perubahan Menjadi Perumda & Perubahan Menjadi Perseroda \\
\hline $\begin{array}{l}\text { Pendirian perusahaan umum } \\
\text { diprioritaskan dalam } \\
\text { menyelenggarakan kemanfaatan umum } \\
\text { berupa penyediaan barang dan/atau jasa yang } \\
\text { bermutu bagi pemenuhan hajat hidup } \\
\text { masyarakat sesuai kondisi, karakteristik dan } \\
\text { potensi Daerah yang bersangkutan } \\
\text { berdasarkan tata kelola perusahaan yang } \\
\text { baik. (Pasal } 8 \text { PP BUMD). }\end{array}$ & $\begin{array}{l}\text { Dalam hal perusahaan umum Daerah akan } \\
\text { dimiliki oleh lebih dari satu Daerah, } \\
\text { perusahaan umum Daerah tersebut harus } \\
\text { merubah bentuk hukum menjadi perusahaan } \\
\text { perseroan Daerah. (Pasal } 334 \text { ayat (2) UU } \\
\text { Pemda). }\end{array}$ \\
\hline $\begin{array}{l}\text { Kedudukan perusahaan umum Daerah } \\
\text { sebagai badan hukum diperoleh pada saat } \\
\text { Perda yang mengatur mengenai pendirian } \\
\text { perusahaan umum Daerah mulai berlaku. } \\
\text { (Pasal } 4 \text { ayat (4) PP BUMD) } \\
\text { Kebutuhan Daerah dikaji melalui studi } \\
\text { yang mencakup aspek pelayanan umum dan } \\
\text { kebutuhan masyarakat di antaranya air } \\
\text { minum, pasar, transportasi. (Penjelasan Pasal } \\
331 \text { ayat (5) UU Pemda) }\end{array}$ & $\begin{array}{l}\text { Kedudukan perusahaan perseroan Daerah } \\
\text { sebagai badan hukum diperoleh sesuai } \\
\text { dengan ketentuan undang-undang yang } \\
\text { mengatur mengenai perseroan terbatas. } \\
\text { (Pasal } 339 \text { ayat (2) UU Pemda Jo. Pasal } 4 \\
\text { ayat (5) dan Pasal 136 PP BUMD) }\end{array}$ \\
\hline
\end{tabular}

Lebih lanjut, pengaturan tentang Perusahaan Umum Daerah sebagaimana dimaksud dalam UU Pemda dan PP BUMD diambil dari konsep Perusahaan Umum dalam UU BUMN, khususnya dalam Penjelasan Pasal 35 ayat (1) bahwa pendirian Perusahaan Umum harus memenuhi kriteria antara lain sebagai berikut:

b. Didirikan tidak semata-mata untuk mengejar keuntungan (cost effectiveness/costrecovery );

C. Berdasarkan pengkajian memenuhi persyaratan ekonomis yang diperlukan bagi berdirinya suatu badan usaha (mandiri). ${ }^{32}$

Dengan demikian, merujuk pada ketentuan

a. Bidang usaha atau kegiatannya Penjelasan Pasal 35 ayat (1) UU berkaitan dengan kepentingan orang BUMN jo. Penjelasan Pasal 331 ayat (5) UU banyak; Pemda jis.Pasal 4 ayat (4) PP BUMD, maka

32 Ibid. Hlm. 16. 
bentuk hukum BUMD yang telah ada sebelum UU Pemda dan PP BUMD yang bergerak di bidang air minum, pasar, maupun transportasi memenuhi kriteria untuk disesuaikan bentuk hukumnya menjadi Perusahaan Umum Daerah. Pengecualiannya adalah apabila akan dimiliki oleh lebih dari satu Daerah, perusahaan umum Daerah tersebut harus merubah bentuk hukum menjadi perusahaan perseroan Daerah sebagaimana dimaksud dalam Pasal 334 ayat (2) UU Pemda. Sebaliknya, bagi BUMD yang telah ada sebelum UU Pemda dan PP BUMD yang modalnya terbagi dalam saham yang seluruhnya atau paling sedikit 51\% (lima puluh satu persen) sahamnya dimiliki oleh satu Daerah sebagaimana diatur dalam Pasal 339 (1) UU Pemda jo. Pasal 5 ayat (2) PP BUMD memenuhi kriteria untuk disesuaikan bentuk hukumnya menjadi Perusahaan Perseroan Terbatas, dengan syarat bahwa kedudukan maupun pengurusannya tunduk pada UU PT. ${ }^{33}$

Baik Perumda maupun Perseroda adalah badan usaha yang berbentuk badan hukum. Berdasarkan Pasal 4 ayat (4) PP No. 54 Tahun 2017, status badan hukum Perumda diperoleh pada saat perda yang mengatur mengenai pendirian Perumda mulai berlaku. Sedangkan untuk Perseroda, berdasarkan Pasal 4 ayat (5) PP No. 54 Tahun 2017, kedudukan Perseroda sebagai badan hukum diperoleh sesuai dengan ketentuan undangundang yang mengatur mengenai PT, yaitu UU No. 40 Tahun 2007. Berdasarkan Pasal 7 ayat (4) UU No. 40 Tahun 2007, Perseroda memperoleh status badan hukum pada tanggal diterbitkannya Keputusan Menteri mengenai pengesahan badan hukum Perseroan. Adapun yang dimaksud dengan badan hukum (rechtspersoon) menurut burgerlijk wetboek (BW) atau KUH Perdata, adalah sekumpulan orang yang di dalam lalu lintas hukum bertindak seakan-akan ia adalah satu badan pribadi tunggal atau corporatie. Sedangkan menurut Van Apeldoorn, badan hukum adalah tiap-tiap kekayaan dengan tujuan tertentu, tetapi tanpa eigenaar atau owner atau pemilik, yang di dalam lalu lintas hukum diperlakukan sebagai badan pribadi. ${ }^{34}$ Sebagai suatu badan hukum, Perumda dan Perseroda diperlakukan sebagai manusia yang memiliki hak dan kewajiban, memiliki kekayaan sendiri, serta dapat melakukan tindakan hukum. Hal ini sesuai dengan teori fiksi (fictie theorie) dari Von Savigny bahwa badan hukum dianggap sebagai hal yang abstrak, tidak nyata karena tidak memiliki kekuasaan untuk menyatakan kehendak, hanya manusia yang memiliki kehendak. Badan hukum dianggap seolaholah manusia. Oleh karena itu, tindakan badan hukum dianggap sebagai tindakan manusia. Jika manusia dalam tindakannya memiliki tanggung jawab maka badan hukum juga

33 Ibid.

34 H. Zainal Asikin dan L. Wira Pria Suhartana, (__ ), Pengantar Hukum Perusahaan, __, __, Hlm. 57-58. 
bertanggung jawab atas tindakan yang dilakukannya. Mengingat badan hukum dianggap sebagai hal yang abstrak karena tidak memiliki kekuasaan untuk menyatakan kehendak, maka organ badan hukum memiliki peran yang sangat penting karena organ itulah yang melakukan pengurusan dan mewakili badan hukum dalam melakukan suatu tindakan. ${ }^{35}$

Dalam menjalankan aktivitas operasinya tersebut, tentu terdapat adanya keuntungan yang diberikan oleh BUMD/ Perusahaan Umum Daerah kepada Pemerintahan Daaerha, adapun bentuk keuntungan yang diberikan Perusahaan Umum Daerah kepada Pemerintah Daerah tersebut tentunya linier dengan tujuan pembentukannya, meliputi:

a. memberikan manfaat bagi perkembangan perekonomian Daerah;

b. menyelenggarakan kemanfaatan umum berupa penyediaan barang dan/atau jasa yang bermutu bagi pemenuhan hajat hidup masyarakat sesuai kondisi, karakteristik dan potensi Daerah yang bersangkutan berdasarkan tata kelola perusahaan yang baik; dan

c. memperoleh laba dan/atau keuntungan. ${ }^{36}$
Secara umum peranan perusahaan BUMD dalam kegiatan perekonomian dan pembangunan daerah dapat dilihat dari 3 aspek, yaitu:
a. Peningkatan produksi;
b. Perluasan kesempatan kerja; dan
c. Peningkatan pendapatan daerah (PAD).

Selain itu, perusahaan umum daerah juga dapat melakukan kerja sama dengan BUMD milik Pemerintah Daerah lain, sehingga dapat mendukung kerja sama antar daerah ${ }^{37}$ yang tentunya juga dapat meningkatkan PAD. PAD dalam hal ini harus menjadi bagian sumber keuangan terbesar bagi pelaksanaan otonomi daerah. ${ }^{38} \mathrm{Hal}$ tersebut menunjukkan bahwa PAD merupakan tolak ukur terpenting bagi kemampuan daerah dalam menyelenggarakan dan mewujudkan otonomi daerah, sehingga PAD mencerminkan kemandirian suatu daerah. BUMD memiliki peran dalam mewujudkan kemakmuran daerah dengan memberikan kontribusi terhadap Penerimaan PAD baik dalam bentuk deviden atau pajak.

Tantangan meningkatkan PAD salah satunya dapat dijawab dengan meningkatkan peran/kontribusi BUMD. Secara makro, peranan BUMD terhadap perekonomian

35 Dina Cahyaningrum, (2018), Implikasi Bentuk Hukum BUMD Terhadap Pengelolaan BUMD, Pusat Penelitian Badan Keahlian DPR RI, Jakarta; Hlm. 65.

36 Pasal 7 Peraturan Pemerintah Nomor 54 Tahun 2017, Lembaran Negara Republik Indonesia Tahun 2017 Nomor 305.

37 Pasal 94 Ayat (7) Peraturan Pemerintah Nomor 54 Tahun 2017, Lembaran Negara Republik Indonesia Tahun 2017 Nomor 305.

38 Chabib Soleh dan Heru Rocmansjah, (2010), Pengeloaan Keuangan dan Aset Daerah, Jakarta: Fokusmedia. Hlm. 68. 
daerah dapat diukur melalui kontribusi nilai tambahnya terhadap Pendapatan Domestik Regional Bruto (PDRB) dan kemampuannya menyerap tenaga kerja. ${ }^{39}$ Adapun fungsi dan peranan lain dari BUMD yang dibebankan kepadanya, meliputi: ${ }^{40}$

1. Melaksanakan kebijakan pemerintah di bidang ekonomi dan pembangunan daerah;

2. Pemupukan dana bagi pembiayaan pembangunan daerah;

3. Mendorong peran serta masyarakat dalam bidang usaha;

4. Memenuhi kebutuhan barang dan jasa bagi kepentingan publik;dan

5. Menjadi perintis kegiatan dan usaha yang kurang diminati swasta.

Secara khusus peran BUMD adalah sebagai salah satu sumber PAD di daerah, maka tentu saja BUMD dituntut agar lebih profesional danlebih efisien dalam melaksanakan usahanya $^{41}$ Dalam melaksanakan kegiatan usahanya, BUMD berorientasi sekaligus kedua motive yaitu bidang bisnis (profit service) dan pelayanan umum (public service), maka ukuran/kriteria peranannya dapat dilihat dari $:^{42}$

1. Kedudukan dalam pasar (market share);

2. Sumbangan pada keungan Pemerintah Daerah; dan
3. Sumbangan

kepada

kegiatan perekonomian dan pembangunan daerah. Sedangkan untuk BUMD yang bergerak di bidang kemanfaatan umum (public utility), maka indikator keberhasilan tersebut akan tampak dari kemampuannya dalam menyediakan barang yang dibutuhkan masyarakat baik dalam kuantitas maupun kualitas yang memadai. ${ }^{43}$ Sebagai salah satu pelaku ekonomi di daerah, BUMD tentunya diharapkan menjadi salah satu penggerak bagi perekonomian daerah, antara lain melalui kegiatan usaha dalam rangka memenuhi kebutuhan masyarakat baik berupa barang maupun jasa. Kemampuan untuk bersaing dengan dunia usaha swasta akan menjadi tolak ukur keberhasilan dalam menjalankan peran tersebut, khususnya bagi BUMD yang bergerak dalam bidang public service dan profit motive.

\section{KESIMPULAN}

BUMD dapat melakukan perubahan bentuk hukum, Perubahan bentuk hukum sebagaimana dimaksud dilakukan dalam rangka mencapai tujuan BUMD dan restrukurasi. Perubahan bentuk hukum BUMD terdiri atas: perubahan bentuk hukum perusahaan umum daerah menjadi perusahaan

39 IR. Purwadi, 2002, Penelitian tentang Strategi Pengembangan BUMD Non Perbankan dalam Meningkatkan Pendapatan Asli Daerah, Surabaya; Balitbang Daerah Provinsi Jawa Timur. Hlm. 3.

40 Rustian Kamaluddin, (__ ), Peran dan Pemberdayaan BUMD Dalam Rangka Peningkatan Perekonomian Daerah, Hlm. 2.

41 Ibid.

42 IR. Purwadi, Op. Cit. Hlm 15.

43 Ibid. 
perseroan Daerah; dan perubahan bentuk hukum perusahaan perseroan Daerah menjadi perusahaan umum Daerah. Adapun perubahan bentuk hukum BUMD sebagaimana dimaksud ditetapkan dengan Perda. Perubahan bentuk hukum BUMD dilakukan dengan terlebih \begin{tabular}{|ccc|}
\hline \multicolumn{3}{|c|}{ Perubahan Menjadi Perumda } \\
\hline Pendirian perusahaan umum & Daerah \\
diprioritaskan & dalam & rangka \\
menyelenggarakan & kemanfaatan & umum
\end{tabular} berupa penyediaan barang dan/atau jasa yang bermutu bagi pemenuhan hajat hidup masyarakat sesuai kondisi, karakteristik dan potensi Daerah yang bersangkutan berdasarkan tata kelola perusahaan yang baik. (Pasal 8 PP BUMD).

Kedudukan perusahaan umum Daerah sebagai badan hukum diperoleh pada saat Perda yang mengatur mengenai pendirian perusahaan umum Daerah mulai berlaku. (Pasal 4 ayat (4) PP BUMD)

Kebutuhan Daerah dikaji melalui studi yang mencakup aspek pelayanan umum dan kebutuhan masyarakat di antaranya air minum, pasar, transportasi. (Penjelasan Pasal 331 ayat (5) UU Pemda)

Adapun bentuk keuntungan yang diberikan oleh BUMD/ Perusahaan Umum Daerah kepada Pemerintahan Daerah, meliputi:

a. memberikan manfaat bagi perkembangan perekonomian Daerah;

b. menyelenggarakan kemanfaatan umum berupa penyediaan barang dan/atau jasa dahulu melakukan kajian paling sedikit terhadap: kesesuaian bentuk hukum, kewajiban; dan kekayaan BUMD. Dalam hal penyesuaian perubahan bentuk BUMD tersebut secara tersirat sudah ada di dalam UU Pemda maupun PP, sebagai berikut:

\begin{tabular}{|c|}
\hline Perubahan Menjadi Perseroda \\
\hline $\begin{array}{l}\text { Dalam hal perusahaan umum Daerah } \\
\text { akan dimiliki oleh lebih dari satu Daerah, } \\
\text { perusahaan umum Daerah tersebut harus } \\
\text { merubah bentuk hukum menjadi } \\
\text { perusahaan perseroan Daerah. (Pasal } 334 \\
\text { ayat (2) UU Pemda). }\end{array}$ \\
\hline $\begin{array}{l}\text { Kedudukan perusahaan perseroan } \\
\text { Daerah sebagai badan hukum diperoleh } \\
\text { sesuai dengan ketentuan undang-undang } \\
\text { yang mengatur mengenai perseroan } \\
\text { terbatas. (Pasal } 339 \text { ayat (2) UU Pemda Jo. } \\
\text { Pasal } 4 \text { ayat (5) dan Pasal 136 PP BUMD) }\end{array}$ \\
\hline
\end{tabular}

yang bermutu bagi pemenuhan hajat hidup masyarakat sesuai kondisi, karakteristik dan potensi Daerah yang bersangkutan berdasarkan tata kelola perusahaan yang baik; dan

c. memperoleh laba dan/atau keuntungan. 
Selain itu, perusahaan umum daerah juga dapat melakukan kerja sama dengan BUMD milik Pemerintah Daerah lain, sehingga dapat mendukung kerja sama antar daerahyang tentunya juga dapat meningkatkan PAD.

\section{DAFTAR PUSTAKA}

\section{Peraturan Perundang-Undangan}

Undang-Undang Dasar Negara Republik Indonesia Tahun 1945.

Undang-Undang Nomor 23 Tahun 2014 tentang Pemerintahan Daerah.

Peraturan Pemerintah Nomor 54 Tahun 2017 tentang Badan Usaha Milik Daerah.

Peraturan Menteri Dalam Negeri Nomor 3 Tahun 1998 tentang Bentuk Hukum Badan Usaha Milik Daerah.

Peraturan Menteri Dalam Negeri Republik Indonesia Nomor 118 Tahun 2018 Rencana Bisnis, Rencana Kerja Dan Anggaran, Kerja Sama, Pelaporan Dan Evaluasi Badan Usaha Milik Daerah.

\section{Buku}

Abdul Halim, (2005), Analisis Investasi, Edisi-2, Jakarta; Salemba Empat.

Abdul Nasir, (2014), Sejarah Sistem Fiskal Migas Indonesia, Jakarta; Grasindo.

Ali Zainudin. (2009), Metode Penelitian Hukum, Jakarta; Sinar Grafika.

Bagir Manan, (1996), Politik Perundangundangan Dalam Rangka Mengantisipasi Liberalisasi Perekonomian, Bandar Lampung; FHUNILA.

Baren Sipayung, (2018), Penyesuaian Bentuk Hukum BUMD Pasca Pemberlakuan PP No. 54 Tahun 2017 tentang BUMD, Perwakilan Provinsi Kalimantan Timur; Subbagian Hukum Badan Pemeriksa Keuangan Republik Indonesia.

Emanuel Sudjatmoko, (2013), dkk, Penelitian Hukum tentang Tanggungjawab Pemerintah Daerah dalam
Menjalankan Fungsi Pemegang Saham (BUMD), Jakarta; Badan Pembinaan Hukum Nasional: Kementerian Hukum dan HAM RI.

F. Ijswara, (1985), Pengantar Ilmu Politik, Cet.8, __ ; Bina Cipta.

Jujun S. Suriasumantri, (2001), Filsafat Ilmu: Sebuah Pengantar Populer, Jakarta; Pustaka Sinar Harapan

Lexy J. Moleong, (2007), Metodelogi Penelitian Kualitatif, Bandung; Rosda.

Moh Nazir, (2005), Metode Penelitian, Jakarta; Ghalia Indonesia.

Peter Mahmud Marzuki, (2007), Penelitian Hukum, Jakarta; Kencana.

Redenbregt, Metode dan Teknik Penelitian Masyarakat, Jakarta, Gramedia, 1978.

Ronny HanitijoSoemitro, (1988), Metodologi Penelitian Hukum dan Jurimetri, Jakarta: Ghalia Indonesia.

Rudy Badrudin, (2011), Ekonomi Otonomi Daerah, Yogyakarta; UPP STIM YKPN.

Sukismo B., (2008), Karakter Penelitian Hukum Normatif dan Sosiologis, Yogyakarta; Penerbit Puskumbangsi Leppa UGM.

Baren Sipayung, (__ $)$, Penyesuaian Bentuk Hukum BUMD Pasca Pemberlakuan PP Nomor 54 Tahun 2017 Tentang $B U M D$, Subbagian Hukum, Badan Pemeriksa Keuangan Republik Indonesia Perwakilan Provinsi Kalimantan Timur.

H. Zainal Asikin dan L. Wira Pria Suhartana, ), Pengantar Hukum Perusahaan,

Dina Cahyaningrum, (2018), Implikasi Bentuk Hukum BUMD Terhadap Pengelolaan $B U M D$, Pusat Penelitian Badan Keahlian DPR RI, Jakarta.

Chabib Soleh dan Heru Rocmansjah, (2010), Pengeloaan Keuangan dan Aset Daerah, Jakarta; Fokusmedia. 
IR. Purwadi, (2002), Penelitian tentang Strategi Pengembangan BUMD Non Perbankan dalam Meningkatkan Pendapatan Asli Daerah, Surabaya;

Rustian Kamaluddin, (_ $)$ Peran dan Pemberdayaan BUMD Dalam Rangka Peningkatan Perekonomian Daerah,

\section{Jurnal}

Ambar Budhisulistyawati, Yudho Taruno Muryanto dan Anjar Sri CN, (_, JuliDesember 2015), Strategi Pengelolaan Badan Usaha Milik Daerah (BUMD) Persero Untuk Mewujudkan Prinsip Tata Kelola Perusahaan Yang Baik, Privat Law Volume III, Nomor 2.

Rudhi Prasetya, (_, _ , 1997), Analisis Ekonomi Terhadap Hukum Kontrak Dalam Menyongsong Era Globalisasi, Jurnal Hukum BISNIS Volume 2, Nomor

\section{Skripsi}

Suparmoko, (_, _, 2002), Analisis Struktur Perekonomian dan pertanian Ekonomi Di Provinsi BantenMelalui Pendekatan LQ, SHIFT SHARE, Skripsi Ilmu Ekonomi Studi Pembangunan, Fakultas Ekonomi, Universitas Negeri Semarang.

\section{Disertasi}

I Ketut Westra, (2012), Kedudukan Hukum Perusahaan Sebagai Badan Usaha Milik Daerah Untuk Meningkatkan Pendapatan Asli Daerah, Ringkasan Disertasi, Malang; Program Doktor Ilmu Hukum Fakultas Hukum Universitas Brawijaya,

\section{Internet}

Fajar Sulaiman, (25 Mei 2015), Legislator: Peran BUMD Penting Dalam Penguatan Ekonomi Daerah, Diakses pada tanggal 25 Agustus 2019, Dari Warta

Ekonomi; https://www.wartaekonomi.co.id/read1 42318/legislator-peran-bumd-penting- dalam-penguatan-ekonomidaerah.html.

Badan Pengawasan Keuangan dan Pembangunan, (3 Juni 2015), Reviu Literatur Pengelolaan Badan Usaha Milik Daerah, Diakses pada 25 Agustus 2019, Dari Badan Pengawasan Keuangan dan Pembangunan: http://www.bpkp.go.id/puslitbangwas/k onten/2291/14.125-Reviu-LiteraturPengelolaan-Badan-Usaha-MilikDaerah.

Anonim, (_, Mei 2018), BAB $X$ Pengembangan Badan Usaha Milik Daerah, Diakses pada tanggal 25 Agustus, —_ Dari Bappeda Jakarta; https://bappeda.jakarta.go.id/uploads/d ocument/2018-05 28/63/63_Bab_10_RPJMD_DKI_202 2.pdf. 